International Journal of Business Management and Economic Review

Vol. 4, No. 06; 2021

ISSN: 2581-4664

\title{
THE IMPACT OF IMPROVED SEED SUBSIDIES ON CEREAL YIELDS IN BURKINA FASO: THE CASE OF RICE
}

\author{
Sacré Cloli Atsamekou Akouelamouai , Christ Durhel YILA MOUTELET and Prince Gwladys ONDONGO \\ Université Marien Ngouabi Faculty of Economics and LARES
}

http://doi.org/10.35409/IJBMER.2021.3346

\begin{abstract}
After the Food crisis in 2008, the Burkinabe State has adopted the input subsidy polycies among which, we have the improved seed subsidies. The objective of this work is to evaluate the impact of that policy "improved seed subsidies" on rice yields. For this purpose, the two steps method of Heckman has been used in the goal to solve the bias problem provoked by the characteristics observables and unobservables that are ables to influence the results. The results show that improved seed subsidies have a positive impact on rice yields. That impact is $275.0639 \mathrm{~kg} / \mathrm{ha}$.
\end{abstract}

Keyword: Subsidy, Improved seeds, Yield, Rice, Burkina Faso.

\section{INTRODUCTION}

Agriculture is an important sector in the economies of developing countries, especially in Africa. For African countries, agriculture is the source of economic growth and an instrument for poverty reduction. In Burkina Faso, agriculture contributes on average more than $35 \%$ to the formation of gross domestic product (DPSAA, 2012) with a participation rate of the active population, estimated at $80 \%$ in rural areas (Savadogo et al, 2016). In terms of nutrition, household food consumption in the country is traditionally based on cereals such as maize and rice whose shares in the diet are estimated at about $16 \%$ and which are grown by $78.6 \%$ of agricultural households (RGA, 2006). Rice is among the most consumed cereals by the population with the selfconsumption rate estimated at 25\% (Sanou, 2013). Also, cereal agriculture is the main source of income for households in rural areas and the pillar of food security in the country. However, although it is the sector that occupies an important place in the Burkinabe economy, agriculture is characterized by low productivity. Indeed, between 1983 and 2007, the growth rate of agricultural production was $4.3 \%$. This rate is lower than the $6.8 \%$ rate that would enable the Millennium Development Goals (MDGs) to be achieved in terms of hunger reduction.

According to the World Bank, the average annual yield of cereal production was estimated at 860kg/ha from 1985 to 2009 in Burkina Faso compared to $1765 \mathrm{~kg} / \mathrm{ha}$ in Côte d'Ivoire,1359kg/ha in Ghana during the period 2004 to 2008. The average yields for rice are estimated at $800 \mathrm{~kg} / \mathrm{ha}$ (DGESS, 2013) while the average yields in India are $3300 \mathrm{~kg} / \mathrm{ha}$ for rice, $2800 \mathrm{~kg} / \mathrm{ha}$ for wheat (FAOSTAT, 2010). Thus, the agricultural sector in Burkina Faso is not sufficiently productive in terms of yields, while it abounds in its midst with a large share of the country's active population. This situation of low agricultural yields is due to several factors, some of which are natural, such as climatic hazards, soil poverty, and also to the low use of improved seeds. Indeed, the adoption of new technologies remains a means for producers to increase their productivity and income. In 


\section{International Journal of Business Management and Economic Review}

Vol. 4, No. 06; 2021

ISSN: 2581-4664

addition to its importance in increasing yields, the adoption of new technologies is also important as an alternative to extensive farming (Basse et al, 2014). Tsongo (1993) showed that the introduction of improved varieties (of bean, potato and maize) in Zaire (now DRC) increased the yields of these cereals; Ntsama et al. (2007) also found that the use of the improved variety "CMS 8704" of rice had a positive impact on rice yields in southern Cameroon. Indeed, Diagne et al. (2012) in a study, confirm that the adoption of the rice variety 'NERICA' in West Africa has had positive effects on rice yields.

Despite the importance of improved seeds in improving productivity, Burkinabe farmers use them very little. According to Bikienga (2002), the use of improved seed for the main food crops has always been low in Burkina Faso, with the remaining needs being met mainly with seed collected by farmers from their own harvest. During the 2000/2001 agricultural season, a survey also estimated that out of a theoretical need of 3572 tons of improved seeds, only 251,240 tons were disseminated in rural areas, i.e. a coverage rate of $0.82 \%$. The use of improved seeds in Burkina remains low, 2.4 to $6 \%$ on average of all seeds (Bikienga, 2002). Indeed, the rate of use of improved seeds for cereals remains low, $15 \%$ for maize and $11.3 \%$ for rice (CEFCOD final report, 2013).

The low use of improved seeds by producers can be explained by several reasons, including the low level of income of these households and their lack of access to bank loans due to the lack of convincing guarantees (RGA, 2008). For these reasons, the purchase of improved seeds by producers remains a difficult operation. In such a circumstance, public policies oriented towards supporting agricultural producers play an important role. Subsidies in the agricultural sector can be used to stabilise prices, regulate markets, develop agricultural sectors or modernise farms. Particularly for the development of agricultural sectors, the State can proceed by subsidizing improved seeds to support producers. Indeed, following the global food crisis that Burkina Faso experienced in 2008 in the form of soaring prices for basic foodstuffs, the Burkinabe government put in place policies to improve food security, reduce poverty and boost economic growth. Among the measures taken, the price subsidy for improved seeds implemented from the 2008/2009 agricultural season is one of the most important (FAO, 2014).

Among the works on the notion of the effect of improved seed subsidy on agricultural yields, Gerald et al. (2013), Gilbert et al. (2013) argue that improved seed subsidy has a positive impact on yields. These authors find that the policy of subsidizing improved seeds is important to ensure food security. However, Cartel et al (2016) through a study conducted in Kenya show that subsidizing improved seeds is an ineffective way to achieve the goal of poverty reduction. Liverpool-Tasie (2012) uses data from Kano district in Nigeria and presents results on subsidy which are little different from studies conducted in Africa. The results obtained show that farmers who participate in the subsidy program tend to be poorer than non-participants.

In view of the above, it appears that the impact of the improved seeds subsidy policy on yields and on the standard of living of producers is not unanimously agreed upon. It is therefore important to evaluate the impact of improved seeds subsidies on yields in order to contribute to the assessment of the impact of this public policy on agricultural yields and to enable the government to reinforce or reorient its policy in terms of improved seeds subsidies. To this end, this study will use the methodological strengths of impact assessment to answer the question: what is the impact of improved seed subsidies on cereal yields in Burkina Faso?

In line with the vision of the Burkinabe government, which is to increase agricultural yields in 


\section{International Journal of Business Management and Economic Review}

Vol. 4, No. 06; 2021

ISSN: 2581-4664

order to ensure food security, the main objective of our study is to assess the impact of improved seed subsidies on cereal yields. It is specifically about :

1-evaluate the impact of improved seed subsidies on rice yields

From this objective follows the following assumption:

1-the subsidy of improved seeds has a positive impact on rice yields.

The rest of our work is organized in three sections. The first section is devoted to the literature review. Section 2 is reserved for the methodological approach. The third section presents the results of the study.

\section{LITERATURE REVIEW}

The consensus on intensifying the use of agricultural inputs is not recent. As early as the 1950s, according to Fontaine (1991), it gave rise to policies to support the use of inputs through subsidies. Indeed, the subsidy of improved seeds is basically part of the public intervention in the agricultural sector, which is one of the sectors of an economy. This section presents the theoretical appreciation of public intervention in an economy and the empirical work on the impact of improved seed subsidy on agricultural yields.

\subsection{Theoretical conception of public intervention}

Grant-making is an important means of action for local authorities. Simple to implement, it makes it possible to pursue public service missions and meet the needs of the population without having to set up heavy administrative structures. Thus, the subsidy is one of the measures of public intervention that has always been the subject of theoretical debates opposing two types of conception, namely the Neoclassicals and the Keynesians (Pouch, 2002).

Neoclassical theory contains normative tools for establishing criteria for evaluating public decisions. From a simple model with two agents, a producer and a consumer, maximising their profit and utility, it is established that the confrontation of supply and demand allows the setting of an equilibrium price on the market, which is accompanied by the hypothesis of pure and perfect competition. This equilibrium is only Pareto optimal if the distribution of goods cannot be changed in favour of one agent without harming another agent. The formation of a Pareto optimal equilibrium makes it possible to assess the effects of a policy of intervention on the market, in particular a policy aiming to act on the price, such as a subsidy. Thus, for neoclassicists, any action on price modifies the distribution of goods and leads to distortions and therefore has a negative effect on the well-being of agents. The Pareto criterion evoked by neoclassicals considered from this point of view that public intervention on a market is inefficient because the mechanisms acting on the market are defined as an efficient mode of resource allocation. Gould J.P and Ferguson C.E (1966) affirm that the State must abstain to let the market fix the optimo-Paretian equilibrium so that the distribution of goods between agents is not subject to any modification. Thus, for them, agriculture, as a sector producing goods for human or animal consumption, cannot be distinguished from the rest of the economy from this point of view, and if aid to farmers is justified, it must be paid for social reasons and not to stimulate production or exports. In the same vein, Boulanger (2005) states that public intervention through the distribution of subsidies among farms generates strong disparities (inequalities) between departments. The author also underlines the negative effect of public policies (subsidies, aids) intended to support producers in the agricultural sector. Rahal et al (2005) criticize public intervention in the agricultural sector, especially measures aimed 


\section{International Journal of Business Management and Economic Review}

Vol. 4, No. 06; 2021

ISSN: 2581-4664

at supporting domestic prices or subsidizing production. According to these authors, this form of support encourages overproduction, which eliminates imported products from the market. They consider price support as amber support, which in reference to the amber light for traffic, means "to slow down". Rahal and Benterki try to make it clear that domestic price subsidies are a factor that can slow down economic growth.

However, according to the Keynesian conception, the price-supply relationship is only stable in the short term. Achieving stability in this relationship therefore requires intervention in the market to guarantee prices that guide production and balance supply and demand. Thus, while reversing the neoclassical postulate, the Keynesian conception asserts that the legitimacy of an agricultural policy (subsidy, aid, etc.) can therefore be seen as a response to market instability. Broussard J-M (1994), supports the Keynesian idea, stipulating that market instability generates the loss of agents' welfare and that public intervention remains an adequate means to improve this welfare. According to Kabaka (2016), the last financial crisis known as the subprime crisis triggered in the United States and which swept across the world has come to remind us that the market economy cannot be left to its own devices or else, the economy will be exposed to crises. The so-called selfregulating mechanisms of the market, which are supposed to prevent crises, have never worked since the 1929 crisis. Therefore, the state has an important role to play in preventing crises and in reviving economies after financial disasters. The author also reminds us that, due to its deficiencies, the market does not always function in such a way as to safeguard the interests of all agents, ensure its survival and avoid crises. This is why the State must intervene to protect the common interests and ensure the optimal functioning of the economy. Barde (1991) also supports the idea of state intervention, but this time state intervention is justified to offset externalities. According to the author, the market failures induced by externalities constitute an important cause of deterioration and waste of resources. To this end, the author assures that the intervention of the State is of great importance in this case, to correct the failures of the market generated by the externalities.

\subsection{Empirical work on the impact of improved seed subsidies on agricultural yields}

There is empirical work devoted to the impact of improved seed subsidy on agricultural yields. Carter et al (2014), in a study in Mozambique show that subsidy of improved seeds has a positive impact on agricultural yields. Bola et al (2011) studied in Nigeria, the impact of subsidy of improved rice varieties on farmers' income. Indeed, they found that the subsidy of improved rice varieties acts positively on yields and increases farmers' income at a rate of $15.5 \%$. Arouna et al (2012), confirm this result through a study conducted on the effect of the adoption of the rice variety "NERICA" on yields in West African countries.

Chibwana et al (2012) find that there is a positive relationship between improved seed subsidy and maize yields in a study conducted in Malawi. According to these authors, subsidizing improved seeds remains a means of ensuring food security at the national level. They also found that farmers allocate $45 \%$ of the cultivable land to improved seeds than to traditional varieties. Indeed, improved seeds have more advantages than traditional varieties. Tsongo (1993) shows that the introduction of improved seeds in Kivu province (Zaïre) has ensured high yields for maize, bean and potato. These yields are estimated at $1569.00 \mathrm{~kg} / \mathrm{ha}, 2970.00 \mathrm{~kg} / \mathrm{ha}$ and $26192.60 \mathrm{~kg} / \mathrm{ha}$ respectively. While the use of traditional seeds ensures low agricultural yields: $924.31 \mathrm{~kg} / \mathrm{ha}$ for maize, $1994.20 \mathrm{~kg} / \mathrm{ha}$ for beans and $16700.00 \mathrm{~kg} / \mathrm{ha}$ for potatoes. Thus, Tsongo's results confirm 


\section{International Journal of Business Management and Economic Review}

Vol. 4, No. 06; 2021

ISSN: 2581-4664

those of Chibwana et al. (2012) regarding the benefits resulting from the use of improved seeds. Holden (2013) shows that subsidizing improved seeds increases agricultural yields. Also the adoption of improved seeds is a way for the population to ensure food security and escape from poverty. Ouédraogo (2004), studies the impact of research and extension of improved maize varieties in Burkina Faso. The results obtained show that the investments made in the creation of improved varieties and their extension have had a rate of return of $81.28 \%$. Maize is the cereal with the highest yield potential among traditional cereals. Also, these investments in research and extension of improved maize seeds have generated a net social gain estimated at 7,553,681,000 FCFA. Basse (2014), shows that the adoption of improved SAHEL rice varieties has a positive impact on producers' yields in Senegal. Also, these varieties reduce poverty intensity by $19 \%$. However, Cartel et al (2016), through a study conducted in the case of Kenya, show that subsidizing improved seeds is an ineffective way to achieve the poverty reduction objective. Indeed their results contradict those of Basse (2014) regarding the effect of improved seed adoption on the poverty level of producers.

Awotide et al (2011, cited by Basse 2014), showed that access to subsidized seed would increase, on average in Nigeria, rice production and per capita income by $18.5 \%$ and $2.3 \%$ respectively. Lunduka, Ricker-Gilbert, Fisher (2013), Mason, Jayne, Mofya-Mukuka (cited by Solomon, 2015) found that subsidizing modern inputs such as improved seeds leads to increased yields and production of cereals. Also these authors showed that this subsidy has a positive impact on the income of producers and contributes to poverty reduction. This confirms the results found throughout Africa and contradicts the results of Carter et al. (2016), regarding the impact of subsidized improved seeds on poverty levels.

\section{METHODOLOGY}

In this part of our work, we present the method used, the data used and the variables of the study.

\subsection{Presentation of the method used}

For a long time, there has been debate in the literature as to whether the impact of a programme or public policy can be reliably evaluated without the use of an experimental approach. The work of Heckman (1997), Ichimuri, Todd (1998 cited by Fougère) provides some answers to this question. These authors have tried to compare the results of non-experimental methods with those obtained with randomized experimentation, and they note that non-experimental methods are conditioned by hypotheses specific to each method for dealing with the selectivity problem. We therefore understand that in impact evaluation, the use of nonexperimental methods is highly dependent on the context of the observation. This context determines in particular the use of this or that type of method in order to reduce the bias in the evaluation problem (Fougère, 2010). Since the program under study may present the problem of selection bias, it would be advisable to take into account, in addition to the biases due to observable factors, the biases due to unobservables. However, among the non-experimental methods available to us, taking into account the biases due to unobservables, the double difference, the discontinuous regression method, the method of instrumental variables can not be applied in this study because of data constraints. Indeed, the double difference estimator is based on a comparison of participants and nonparticipants before and after the program, whereas we only have post-program data. The discontinuous regression method cannot be applied because the program design does not include the cut-off criterion. As for the method of instrumental variables, it cannot be applied because of the lack of a good 


\section{International Journal of Business Management and Economic Review}

Vol. 4, No. 06; 2021

ISSN: 2581-4664

instrument conditioning the treatment of the program. Heckman's two-stage method was adapted to the data of the program under study and was therefore retained for the analysis of the study. The choice of this method is justified by the reasons listed below:

$\checkmark$ Heckman's method is appropriate for the data at hand and provides a good analysis of the impact of improved seed subsidies on grain yields.

$\checkmark$ With the Heckman method, the selection bias generated by the difference in unobservable characteristics between grant recipients and nonrecipients is overcome.

$\checkmark$ This method's estimator of the impact of treatment on outcomes is asymptotically unbiased (Bayart et al. 2009).

$\checkmark$ Heckman's method is often used to measure the impact of programs in several areas. Indeed, Bayart et al (2009) used the two-stage Heckman method to estimate the impact of survey mode on mobility behavior, Chibwana et al (2012) also used the Heckman method to measure the impact of input subsidy program on land allocation decisions, Yirga et al (2003) used the two-stage Heckman method to see the impact of adoption of new technologies on yields in a study in the case of Ethiopia.

$\checkmark$ Nyemeck et al (2007), also used the two-step Heckman method to assess the counterfactual of what cocoa production would be in the absence of easy access to credit.

$\checkmark$ The advantage of this method is that to estimate the impact of a program or policy, it uses a regression which is a convenient tool to measure the strength of the statistical "link" between two (2) variables and also it is able to resolve the selection bias coming from observable and unobservable characteristics (Green, 2000).

\subsubsection{Specification of the Heckman model}

Consider equation (1), which examines the impact of the improved seed subsidy on yields.

$\boldsymbol{y} \boldsymbol{i}=\boldsymbol{\beta} \boldsymbol{X} \boldsymbol{i}+\boldsymbol{\alpha} \boldsymbol{I} \boldsymbol{i}+\boldsymbol{\mu} \boldsymbol{i}$ (1) where $y \boldsymbol{i}$ is the return, $X \boldsymbol{i}$ a vector of explanatory variables, $I i$ a binary variable indicating whether or not individual $i$ benefited from the subsidy, $\mu i$ the error term. Using the two-stage estimation method developed by Heckman in 1979, the model can be formalised for each individual $\mathrm{i}$ as follows:

$\boldsymbol{I} \boldsymbol{i}=\boldsymbol{\delta} \boldsymbol{Z} \boldsymbol{i}+\boldsymbol{\varepsilon} \boldsymbol{i}(2)$ (selection equation)

$\boldsymbol{y} \boldsymbol{i}=\boldsymbol{\beta} \boldsymbol{X} \boldsymbol{i}+\boldsymbol{\mu} \boldsymbol{i}$ (3) (substantial equation)

The model assumption $\varepsilon i$ Following a normal distribution $\mathrm{N}(0,1) \mu i$ Following a normal distribution $\mathrm{N}(0, \delta \mu)$. Taking all individuals with $(X i, Z i)$ given.

Formally, the regression of $y i$ on $X i$ in the sample is :

$: \mathrm{E}(\boldsymbol{y} \boldsymbol{i} \mid \boldsymbol{I} \boldsymbol{i}=1)=\mathrm{E}(\boldsymbol{y} \boldsymbol{i} \mid \boldsymbol{X} \boldsymbol{i}, \boldsymbol{Z i}, \boldsymbol{I} \boldsymbol{i})(4)$

$: \mathrm{E}(\boldsymbol{y} \boldsymbol{i} \mid \boldsymbol{I} \boldsymbol{i}=1)=\boldsymbol{\beta} \boldsymbol{X} \boldsymbol{i}+\mathrm{E}(\boldsymbol{\mu} \boldsymbol{i} \mid, \boldsymbol{I} \boldsymbol{i}=1)(5)$

By imposing a normality on the variance of $\varepsilon$. Let $\delta \varepsilon=1$. Under the assumption of normality, we can write : $\mu i=\rho \delta \mu \varepsilon i$

By replacing in expression (5), we obtain :

$\mathrm{E}(\boldsymbol{y} \boldsymbol{i} \mid \boldsymbol{I} \boldsymbol{i}=1)=\boldsymbol{\beta} \boldsymbol{X} \boldsymbol{i}+\mathrm{E}(\boldsymbol{\mu} \boldsymbol{i} \mid \boldsymbol{Z} \boldsymbol{i}, \boldsymbol{I} \boldsymbol{i}>0)(6)$

$\mathrm{E}(\boldsymbol{y} \boldsymbol{i} \mid \boldsymbol{I} \boldsymbol{i}=1)=\boldsymbol{\beta} X \boldsymbol{i}+\boldsymbol{\rho} \boldsymbol{\delta} \boldsymbol{\mu} \boldsymbol{i} \mathrm{E}(\boldsymbol{\varepsilon} \boldsymbol{i} \mid \boldsymbol{\varepsilon} \boldsymbol{i}>-\boldsymbol{\delta} \boldsymbol{i Z} \boldsymbol{i})(7)$

The truncation on $\varepsilon i$ thus leads to a truncation on $y i$ if respectively $\mu i$ and $\varepsilon i$ are correlated $(\rho \neq$ $0)$.

The functions $\varnothing$ and $\Phi$ are respectively the density and distribution functions of the normal 


\section{International Journal of Business Management and Economic Review}

Vol. 4, No. 06; 2021

ISSN: 2581-4664

distribution. $\lambda i$ is called the inverse of the Mills ratio. Because of selection bias, if equation (1) is estimated by the ordinary least squares method, one variable $(\boldsymbol{\lambda} \boldsymbol{i}=\emptyset(\boldsymbol{\delta i Z i}) / \boldsymbol{\Phi}(\boldsymbol{\delta i Z i})))$ and the model can be expected to be biased. Indeed, it is likely that the magnitude, sign, and significance of the coefficients differ when estimated by the two-step method. These differences depend on the coefficient $\rho \sigma \mu i$ and the coefficients of the relevant variables estimated in the selection equation (Hoffman and Link, 1984).

The variable $\lambda i$ represents for the observation, the conditional expectation of the residual $\varepsilon i$ à $I i=1$. It also captures the expected values of the equation of interest, once the selection effect is removed. This variable is generally the main source of bias in the estimates of the coefficients of the regression model.

It is now possible to estimate the program impact equation without selection bias by including the inverse of the Mills ratio (Danelutti, 2003) in the substantive equation (equation 3).

Let the model be: $\boldsymbol{y}_{\boldsymbol{i}}=\boldsymbol{\beta} \boldsymbol{X}_{\boldsymbol{i}}+\boldsymbol{\rho} \boldsymbol{\sigma}_{\boldsymbol{\mu}} \boldsymbol{\lambda}_{\boldsymbol{i}}+\boldsymbol{e}_{\boldsymbol{i}}$

For beneficiary I $=1: \boldsymbol{y}_{1 i}=\boldsymbol{\beta} \boldsymbol{X}_{1 i}+\boldsymbol{\rho} \sigma_{\mu 1 i} \lambda_{1 i}+\boldsymbol{e}_{1 i}$

For non-beneficiary I $=0: \boldsymbol{y}_{0 i}=\beta X_{0 i}+\rho \sigma_{\mu 0 i} \lambda_{0 i}+e_{0 i}$

\subsection{Data presentation}

Our study uses data from the household survey, which was conducted by the Ministry of Agriculture. This survey, called the Permanent Agricultural Survey (EPA), is carried out annually by the Ministry's Directorate of Studies and Planning. The survey is conducted in all 45 provinces of Burkina Faso. For this study, we are interested in the 2012/2013 campaign of the Permanent Agricultural Survey. This choice is justified by the fact that it is the most recent database available. Indeed, the main objective of the LFS is to evaluate the areas, yields and productions of the main crops in the rainy and dry seasons. The specific objectives of the LFS are as follows :

$\checkmark$ To estimate the area, yield and final agricultural production by province and country for each crop

$\checkmark$ Carry out cereal crop forecasts in September of each year in order to inform the government and its development partners objectively about the situation of the season at an early stage

$\checkmark$ Make estimates of residual farm stocks in September

It gives the forecast results of the season in October and the final results in February of each year in accordance with the regional mechanism (CILSS). The permanent agricultural survey (EPA) is conducted on the basis of a sample of agricultural households representative of the 45 provinces and 13 regions of the country. The sampling of this survey is designed by a two-stage survey with stratification at the first stage (village) and at the second stage (agricultural household). The villages are drawn by province in proportion to the size of the village, in a systematic way after classification of the villages in order of increasing size. It should be noted that the LFS does not take into account plots in irrigated plains and lowlands, but rather it concerns only rainfed crops. The sample on which our study is based consists of 3649 observations for the whole country, from which we obtain 796 observations for rice.

\section{3 Description and choice of model variables}

The variables of interest in the study are yield and subsidy of improved seeds. The choice of other variables is made based on the literature review and also according to their availability in our database. Following Arouna et al (2013), Chabwana et al (2012), the socio-demographic and socio- 


\section{International Journal of Business Management and Economic Review}

Vol. 4, No. 06; 2021

ISSN: 2581-4664

economic characteristics of a farm household selected are: household size, age of the head of household, sex of the head of household, level of education, marital status, income of the head of household, access to credit. The variables "quantities of fertilizer", "area sown" are retained due to the fact that they are the main factors used by a farmer in the production process Carter et al. (2014).

\section{The explained variable}

The explained variable of our model is the rice yield, it is a quantitative variable expressed in kilograms per hectare $(\mathrm{kg} / \mathrm{ha})$.

\section{The Explanatory variables}

The explanatory variables used are the socio-economic and demographic characteristics of agricultural households, which are: household size, age of the head of the household, sex of the head of the household, level of education, access to credit, household income and other variables such as the area sown, the quantity of fertilizer used, and the subsidy of improved seeds.

Household size: This is the number of people living in one house. The size of the household is a factor that plays an important role in increasing agricultural yields. Indeed, the number of individuals in the household constitutes a workforce for the head of the household. A positive effect is expected for this variable.

Age of head of household: Age is a factor that often affects the productivity level of producers. It is a variable measured by the number of years of age of the producer. Indeed, as the age of the head of the household increases, his or her work force decreases and older people show resistance to the adoption of new technologies, which can have a negative impact on agricultural yields. It is therefore expected that age will have a negative impact on yields.

The sex of the head of the household: It is a binary variable, it takes the value 1 if it is a man and 0 if it is a woman. It is often said that the man has a superior work force than the woman. Indeed, men produce more than women. This variable can have a positive or negative effect on returns. The level of education of the head of the household: This is a binary variable, it takes the value 1 if the head of the household is literate and 0 if he is not literate. According to human capital theory, the level of education of a producer is a factor that has a positive effect on productivity. A positive sign of this variable is expected in the analysis.

Marital status: In our study, this variable takes into account the following modalities: 0 if the head of the household is not married, 1 for the head of the household who is married. It is assumed that a married head of household works a lot to be able to provide for the family, contrary to the other types of individuals (single, widowed, divorced/separated, free union). Therefore, a positive effect of this variable is expected.

Access to credit: This is also a binary variable, taking the value 1 if the household has access to credit and 0 otherwise. Access to credit is a sine qua non condition for the purchase of inputs and is therefore an important factor in increasing agricultural yields. We expect a positive sign for the coefficient of the variable access to credit.

Household income: It represents the financial gain of the household per day or per month. It is a quantitative variable expressed in monetary units (FCFA). The income that a household has at its disposal allows it to buy inputs or to pay a labourer to improve yields. This variable is expected to have a positive influence on yields.

Area planted: The area planted represents the number of hectares used by a household to cultivate 
Vol. 4, No. 06; 2021

ISSN: 2581-4664

maize or rice. It is measured in hectares (ha). When the producer increases the number of hectares under cultivation, his yields also increase. A positive effect of this variable on yields is expected. Quantity of fertilizer used: The quantity of fertilizer is expressed in kilograms (kg). It is represented in this study by the amount of NPK and urea used per household. Most studies (Carter et al, Arouna et al, 2013) show that inputs such as chemical fertilizers positively affect agricultural yields. A positive influence of this variable on yields is expected in this study.

Subsidy of improved seeds: The variable of interest in our study, it is binary and represents the mode of acquisition of improved seeds by the household. This variable takes 1 if the household is a beneficiary and 0 otherwise. Subsidizing improved seeds has a positive impact on agricultural yields (Carter et al, 2014; Chibwana et al, 2012).

Table 1: Description of variables and their expected sign Variables

\begin{tabular}{|c|c|}
\hline Variables & Expected sign \\
\hline Household size & + \\
\hline $\begin{array}{lll}\begin{array}{l}\text { Age of head of } \\
\text { household }\end{array} & & \\
\end{array}$ & - \\
\hline $\begin{array}{l}\text { The sex of the head of } \\
\text { the household }\end{array}$ & $+/-$ \\
\hline $\begin{array}{l}\text { The level of education } \\
\text { of the head of the } \\
\text { household }\end{array}$ & + \\
\hline Marital status & + \\
\hline Household income & + \\
\hline Area planted & + \\
\hline Access to credit & + \\
\hline $\begin{array}{l}\text { Subsidy of improved } \\
\text { seeds }\end{array}$ & + \\
\hline
\end{tabular}

Source: Author, table based on literature

\section{RESULTS}

In this part of our study, the descriptive statistics of the model variables and the results of the estimation of the impact of the improved seed subsidy on rice yields will be presented. Two (2) categories of variables are used in our study: quantitative variables and qualitative variables.

The descriptive statistics of these variables are presented in Tables 2 and 3 for quantitative and qualitative variables respectively.

\subsection{Descriptive statistics of the quantitative variables of the model}

The average age of the farmers in our sample is 45 years for maize farmers and 34 years for rice farmers. The average quantities of fertilizer used are: $43.81156 \mathrm{~kg}$ of NPK, $13.14824 \mathrm{~kg}$ of Urea per producer for rice production. The average area planted by each producer is 0.21 ha for rice. Rice producers have an average income of 181426.6 FCFA. The average household size in this 
International Journal of Business Management and Economic Review

Vol. 4, No. 06; 2021

ISSN: 2581-4664

sample is 12 persons per household. The average yields of rice farmers are $1559.548 \mathrm{~kg} / \mathrm{ha}$.

Table 2: Descriptive statistics for quantitative variables

\begin{tabular}{|lllll|}
\hline Variables & Average & $\begin{array}{l}\text { Standard } \\
\text { deviation }\end{array}$ & MIN & MAX \\
\hline \hline Age of head of household & 34 & 12.9949 & 14 & 71 \\
NPK & 43.81156 & 35.62911 & 0 & 100 \\
Urea & 13,14824 & 44.00041 & 0 & 400 \\
Area for rice & 0.2108815 & 0.3060192 & 0.0042 & 2.8 \\
Income of rice production & 181426.6 & 249837.3 & 2000 & 2160000 \\
Household size & 12.46135 & 7.538551 & 1 & 88 \\
Rice yield & 1559.548 & 723.3445 & 81.25 & 4000 \\
\hline
\end{tabular}

Source: Author's estimate based on LFS 2012/2013 data

\section{2 Descriptive statistics of the qualitative variables of the model}

In our sample, $69.22 \%$ of men and $30.78 \%$ of women produce rice. There are $75.73 \%$ of married and $24.87 \%$ of unmarried rice producers. The level of education of rice producers is $31.28 \%$ literate and $68.72 \%$ non-literate. For rice production, $84.30 \%$ of producers have no access to credit and $15.70 \%$ have access to credit.

Table 3 : Descriptive statistics for categorical variables in the model

\begin{tabular}{|l|l|l|l|}
\hline Variables & Fréquence & Pourcentage & Fréquence cum \\
\hline Gender & & & \\
\hline Male & 551 & 69.22 & 100 \\
\hline Woman & 245 & 30.78 & 30.78 \\
\hline Level of education & & & \\
\hline educated & 249 & 31,29 & 100 \\
\hline No educated & 547 & 68.72 & 68.72 \\
\hline Marital status & & & \\
\hline Not married & 198 & 24.87 & 24.87 \\
\hline
\end{tabular}


International Journal of Business Management and Economic Review

Vol. 4, No. 06; 2021

ISSN: 2581-4664

\begin{tabular}{|l|l|l|l|}
\hline \hline Married & 598 & 75,73 & 100 \\
\hline Access to credit & & & \\
\hline No & 671 & 84.30 & 84.30 \\
\hline Yes & 125 & 15.70 & 100 \\
\hline
\end{tabular}

Source: Author's estimate based on LFS 2012/2013 data

4.3 The results of the estimation of the impact of the subsidy of improved seeds on rice yields. In this section, we will present the results of the second stage of the Heckman model by discussing the impact of improved seed subsidy on rice yields and present the effect of different control variables on rice yields.

Table 4 presents the results of the 2-step Heckman modelefor estimating the impact of improved seed subsidy on rice yields. The inverse of the Mils ratios estimated in the model is significant at the $1 \%$ level. This shows that the selection bias related to unobservable variables has been corrected.

The coefficient of the variable "subsidy of improved seeds" is positive and significant at the $1 \%$ level. This means that the subsidy of improved seeds has a positive impact on rice yields and the impact obtained is $275.0639 \mathrm{~kg} / \mathrm{ha}$. In other words, the policy of subsidizing improved seeds has a positive impact on cereal yields. These results confirm the results of Carter et al (2014), Chibwana et al (2012), Bale et al (2011) who also found that improved seed subsidy has a positive impact on crop yields.

Table 4: Impact of improved seed subsidy on rice yields

\begin{tabular}{|l|l|l|}
\hline Rice yield & Coefficients & $\mathrm{P}>/ \mathrm{t} /$ \\
\hline Subsidy for improved seed & 275.0639 & $0.000^{* * *}$ \\
RIM & 402.0298 & $0.000^{* * *}$ \\
R2 & 0.8558 & \\
Prob $>\mathrm{F}$ & 0.000 & \\
\hline
\end{tabular}

$*=$ significance at $10 \%, * *=$ significance at $5 \%, * * *=$ significance at $1 \%$.

Source: Author's estimate from LFS 2012/2013 data

The results in Table 5 show that the coefficient of the variable "Area" is positive and significant at the 5\% level, which means that an increase in the number of hectares of a plot leads to an increase in rice yield. The gender of the head of the household also has a positive influence on rice yields at the $1 \%$ level. Also for the variable "Quantity of fertilizer", Urea and NPK have positive and significant coefficients at the $1 \%$ threshold. This means that when the quantities of Urea and NPK used by the household increase, the household rice yields also increase. However, the results show that household size has a negative and significant coefficient (1\% threshold), which means that household size has a negative impact on rice yields. Similarly, the results show that the coefficient of the variable "level of education" is negative and significant at the 5\% threshold. This means that when the level of education of the head of the household increases, his yields decrease. This is contrary to the postulate of the human capital theory, but consistent with the results of Philips 
Vol. 4, No. 06; 2021

ISSN: 2581-4664

(1987), Appleton (2000) who also found that the level of education has a negative impact on productivity. Also the age of the household head has a negative and significant coefficient at 5\%, which translates that the age of the household head has a negative impact on rice yields. This result is explained by the fact that when the age of the head of household increases, his work force decreases, which leads to a decrease in his productivity. The constant of the model is positive and significant at $1 \%$. The variables Marital status, Access to credit, Household income are not significant.

Table 5: Effect of control variables on rice yields

\begin{tabular}{|lll|}
\hline Yields & Coefficient & $\mathrm{P}>|\mathrm{t}|$ \\
\hline Constant & 818.4035 & $0.000^{* * *}$ \\
Size of head household & -6.248719 & $0.000^{* * *}$ \\
Age of head of household & -2.309604 & $0.009^{* * *}$ \\
Gender of head of household & 110.9116 & $0.001^{* * *}$ \\
Level of education & -55.27404 & $0.024^{* *}$ \\
Marital status & 30.27662 & 0.276 \\
Household income & -0.000242 & 0.595 \\
Area & 84.80411 & $0.026^{* *}$ \\
Access to credit & 0.7767954 & 0.979 \\
NPK & 11.45789 & $0.000^{* * *}$ \\
Urea & 1.009066 & $0.000^{* * *}$ \\
R2 & 0.8558 & \\
Prob>F & 0.000 &
\end{tabular}

$*=$ significance at $10 \%, * *=$ significance at $5 \%, * * *=$ significance at $1 \%$.

Source: Author's estimate based on LFS 2012/2013 data

\section{CONCLUSION}

This study estimated the impact of improved seed subsidies on rice yields in Burkina Faso. The impact assessment was done using the two-stage Heckman method, which allowed the study to take into account observable and unobservable factors that may influence the estimation results. The results obtained show that the subsidy of improved seeds has a positive and significant impact on rice yields. The values of the impact of improved seed subsidy on rice yields are 275.0639 $\mathrm{kg} / \mathrm{ha}$. The results also show that fertilizer, area have a positive impact on rice yields. Indeed, both types of fertilizers Urea and NPK have a positive impact on rice yields. The results in Table 6 show that the coefficient of the variable "Area" is positive and significant at the 5\% level, which means that increasing the number of hectares of a plot increases rice yields. However, the variables gender, household size and education level have a negative effect on rice yields. The variables marital status, access to credit, and household income had no effect on rice yields.

\section{REFERENCES}

Appleton, S. (2000). Education and Health at the Household Level in Sub-Saharan Africa. Harvard University: Center for International Development. 


\section{International Journal of Business Management and Economic Review}

Vol. 4, No. 06; 2021

ISSN: 2581-4664

Arouna, A., \& Diagne, A. (2013). Impact de l'adoption de semence riz sur les rendements et le revenu des ménages agricoles: une étude de cas du bénin.4th International Conference of the African Association of Agricultural Economics.

Attafi, J. (2014). La méthode du matching :Solution pour le problème de l'évaluation d'impact.

Barbe, J. (1991). Economie et politique de l'environnement, PUF Paris

Basse, W. (2014). Impact de l'adoption des variétés améliorées de riz SAHEL sur la pauvrété: Approche de l'effet marginal du traitement (EMT).Laboratoire de recherche en économie de SaintLouis. Faculté des sciences économiques et de gestion

Bayart, C., \& Bonnel, P. (2009). Impact d'enquête sur les comportements de mobilité. Laboratoire d'économie des transports, ENTP, Université lumière lyon 2, CNRS

Bikienga, M. (2002). Une évalution des secteurs des engrais et des semences au BurkinaFaso,ATRIP.

Broussard, J. (1994). Revenus, marchés et anticipations: la dynamique de l'offre agricole, Economie rurale 220-221, mars-juin,P.61-68.

carter, M. (1989). The impact of Credit on Peasant productivity and Differentiation.Nicarragua Jounal of Development Economics, $n^{\circ} 28, P$ 83-103.

Carter, M., Laajaj, R., \& Yang, D. (2014). Subsidies and persistence of technology adaptation: Field experimental Evidence from Mozambique, NBER, Working Paper 20565

Carter, M., Laajaj, R., \& Yang, D. (2016). Savings subsidies and technology adoption: Field experimental evidence from Mozambique, Working Paper

Chibwana C, Monica F, Shively G. (2012). Cropland allocation effecfs of agriculture inputs subsidies in Malawi.

CEFCOD. (2013). Situation de Réference des principales filières Agricoles au Burkina Faso.Rapport final .

Danelutti, T. (2003). Une étude sur la consommation de biére, de vin et de spiritueux en Suisse. Ecole des HEC-Université de lausanne.Statistique et Econométrie Appliquée

DGESS. (2014). Rapport d'évaluation des opérations de distribution d'intrants et d'équipements agricoles.

DPSSA. (2012). Equipements et infrastructures agricoles, rapport d'analyse,31p.

FAO. (2014). Analyse des incitations par les prix pour le mal̈s au Burkina Faso pour la période 2005-2013. Rapport p16.

Fontaine, J., \& Sindzingre, A. (1991). Macro-micro linkages:Structural adjustment and fertilizer policy in sub-saharan Africa (Technical Papers) $N^{\circ} 49$.

Fougere, D. (2010). Les méthodes économétriques d'évaluation, Revue Française des affaires sociales, $n^{\circ} 1-2$.

Gould, J., \& Ferguson, C. (1966). Microeconomic theory, Richard D. Inwin, Inc.

Green, W. (2000). Econometric Analysis. Ed New Jersey: Prentice-Hal,1 2000.

Heckman, J. (1979). Sample selection bias as a specification error. Economica, vol.47, No.1.

Heckman, J. (1997). Instrumental Variables: A Study of Implicit Behavioral Assumptions Used in Making Programm Evaluations. Journal of Human Ressources, Vol. $32 n^{\circ} 3$.

Hoffman, D., \& Link, C. (1984). "Selectivity bias in male wage equation: black-white comparison", The review of Economics and Statistics, Vol.66 n'22, pp.320-324. .

Kabaka, I. (2016). L'intervention de l'Etat dans l'économie: du laisser-faire à la régulation.

Liverpool, T. (2012). Target Subsidies and Private Market Participation. An Assessment of 
International Journal of Business Management and Economic Review

Vol. 4, No. 06; 2021

ISSN: 2581-4664

Fertilizer Demand in Nigeria.International Food Policy, Reseach Institute Discussion Paper 01194.

Mason, N., \& Smale, M. (2013). Impacct of subsidized hybrid seed on indicator of economic wellbeing among maize growers in Zambia.

Mason, N., \& Tombo, S. (2015). Do input subsidies reduce poverty among smallholder farm households? Evidence from Zambia.

Minot, N., \& Benson, T. (2009). Fertiliser Subsidies in Africa, Are Vouchers the Answer?, IFPRI Issue Brief 60, July 2009.

Ntsama, S., \& Kamgnia, B. (2007). Les determinants de l'adoption des variétés améliorées de maÏs: adoption et impact de la CMS 8704.Université de Yaoundé Soa, BP18 Yaoundé (Cameroun) Nyemeck, J., \& Nkamleu, G. (2007). The role of credit access in improving cocoa production in West Africa counries. AAAE Conference proceedings.

Ouedraogo, S. (2004). Impact économique de la recherche et de la vulgarisation des variétés améliorées du maïs au Burkina Faso.

Phillips, J. (1987). A Comment on Farmer Education and Farm Efficiency: A Survey. Economic Development and Cultural Change.

Pouch, T. (2002). L'agriculture entre théorie et histoire ou qu'est-ce qu'une politique agricole.

Rahal, A., \& Benterki, A. (2005). Les subventions agricoles: Entre théories et pratique.

Savadogo, K., Combary, O., \& Akouwerabou, D. (2016). Impacts des services sociaux sur la productivité agricole au Burkina Faso: approche par la fonction distance output.Revue: Mondes en développement. Vol 44-1016/2-n $n^{\circ} 174$

Tsongo, M. (1993). Impact de l'introduction d'une innovation sur le développement des exploitations paysannes dans les zones montagneuses du Kivu (Zä̈re).

Yirga, C., \& Hassan, R. (2003). Determinants of inorganic fertiliser use in the mixed croplivestock farming systems of central highlands of Ethiopia. 